AperTO - Archivio Istituzionale Open Access dell'Università di Torino

\title{
Validation of a GC/MS method for the detection of two quinoline-derived selective androgen receptor modulators in doping control analysis
}

\section{This is the author's manuscript}

Original Citation:

Availability:

This version is available http://hdl.handle.net/2318/86557

since 2015-12-29T09:24:46Z

Published version:

DOI:10.1007/s00216-010-4569-8

Terms of use:

Open Access

Anyone can freely access the full text of works made available as "Open Access". Works made available under a Creative Commons license can be used according to the terms and conditions of said license. Use of all other works requires consent of the right holder (author or publisher) if not exempted from copyright protection by the applicable law. 


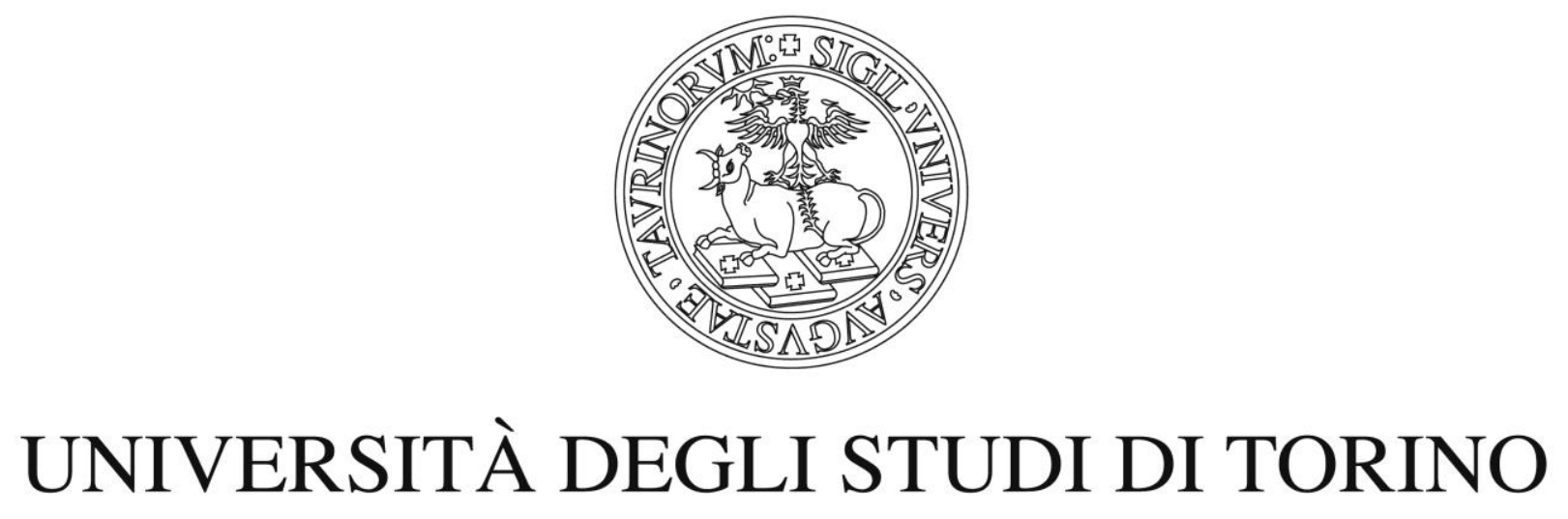

This is an author version of the contribution published on:

Questa è la versione dell'autore dell'opera:

Analytical Bioanalytical Chemistry, 400, 1, 2011, DOI: 10.1007/s00216-010-4569-8

E. Gerace, A. Salomone, F. Fasano, R. Costa, D. Boschi, A. Di Stilo, M. Vincenti volume 400, Springer, 2011, 137-144

The definitive version is available at:

La versione definitiva è disponibile alla URL:

http://link.springer.com/article/10.1007\%2Fs00216-010-4569-8 


\section{Abstract}

Selective androgen receptor modulators (SARMs) represent an emerging class of drugs likely to be abused in sport. For clinical applications, these substances provide a promising alternative to testosterone-replacement therapies and their advantages include oral bioavailability, androgen receptor specificity, tissue selectivity, and the absence of steroid-related side effects. Although not yet commercially available, since January 2008 SARMs have been included on the prohibited list issued yearly by the World Anti-Doping Agency (WADA), so control laboratories need to update their procedures to detect either the parent drugs or their metabolites. Within this context, two quinolinone SARM models were synthesized and automatically characterized to update the existing routine screening procedures. The conditions for the new target analytes are compatible with the existing laboratory protocols used for both incompetition and out-of-competition controls and can be included in them. Validation parameters according to ISO 17025 and WADA guidelines were successfully determined. For analytical determinations, spiked urine samples were hydrolyzed and extracted at $\mathrm{pH} 9.6$ with $10 \mathrm{~mL}$ of tert-butyl methyl ether. Then, the analytes were subsequently converted into trimethylsilyl derivatives and detected by gas chromatography-mass spectrometry. The absence of interferents, together with excellent repeatability of both retention times and the relative abundances of diagnostic ions, allowed proper identification of all SARM analytes. The analytes' quantification was linear up to $500 \mathrm{ng} / \mathrm{mL}$ and precision criteria were satisfied (coefficient of variation less than $25 \%$ at $10 \mathrm{ng} / \mathrm{mL}$ ). The limits of detection were $1 \mathrm{ng} / \mathrm{mL}$ for both SARMs, whereas recovery values were between 95.5 and $99.3 \%$. The validated method can be efficiently used for urine screening of the 2-quinolinone-derived SARMs tested.

\section{Keywords}

Gas chromatography-mass spectrometry. Doping control. Selective androgen receptor modulators . Urine screening . Validation 


\section{Introduction}

Endogenous androgens are essential for male development, spermatogenesis, and the maintenance of male secondary characteristics, such as bone mass, muscle mass, and body composition [1]. In recent years, testosterone has been used to treat hypogonadism, muscle wasting, osteoporosis, cancer cachexia, anemia, age-related frailty, for male contraception, and as hormone-replacement therapy in aging men [2-5]. The limited oral bioavailability of testosterone as well as the need to differentiate desired anabolic from undesired androgenic effects led to the synthesis, and clinical testing, of numerous derivatives of anabolic androgenic steroids such as nandrolone decanoate and stanozolol that have been shown to increase bone mass by stimulation of bone formation [6, 7]. However, serious side effects associated with steroid-replacement therapies, including hepatic toxicity, decreased levels of HDL cholesterol, gynecomastia, and prostatic and cardiovascular illness [8-10], have driven research toward drugs with different mechanisms of action. From this research, selective androgen receptor modulators (SARMs) emerged as a new class of promising drugs. SARMs represent a novel class of drugs for the treatment of various debilitating diseases, muscle wasting, osteoporosis, and for male contraception [11-17]. Major advantages of these drugs are the tissue-selective anabolic properties combined with considerably reduced side effects commonly associated with steroidreplacement therapies [18]. In fact, the metabolism of these drugs does not involve the enzymatic activities that are responsible for testosterone metabolism and, in particular, its transformation by aromatase and $5 a-r e d u c t a s e ~ e n z y m e s ~[14,19]$. A series of orally bioavailable SARMs with various chemical structures were prepared and submitted to advanced clinical trials [20-22] as well as metabolic and spectrometric studies [23-28]. Currently investigated SARMs can be categorized by their common core structures into five classes: arylpropionamide, bicyclic hydantoins, quinolines, tetrahydroquinolines, and 4-azasteroids. Owing to their properties, SARMs are likely to be attractive to athletes, as these drugs offer the anabolic effects without the androgenic effects which are commonly associated with traditional anabolic androgenic steroid misuse. Although these drugs are not clinically approved yet, the availability of these substances on the black market was recently recognized [29]. On the basis of these facts, SARMs were added to the prohibited list issued annually by the World Anti-Doping Agency (WADA) since January 2008 [30]. Therefore, in recent years, several doping control analytical assays have been developed for arylpropionamide-, hydantoin-, quinoline-, and tetrahydroquinoline-derived SARMs [31-37] to establish new screening and confirmation procedures or to update existing assays with these target compounds. Moreover, additional in vivo and in vitro metabolism experiments were conducted and the detection of major metabolites was implemented in existing sport drug testing [25, 38, 39]. Although several methods for the detection of SARMs employing liquid chromatography-tandem mass spectrometry (MS) techniques were recently described, the analysis of this class of substances using conventional 
gas chromatography (GC)/MS approaches would be a useful complementary method as GC/MS systems are still an extensively employed tool in sport drug testing [40]. In the present work, two quinolinone-derived SARMs that possess tissue-selective androgen receptor agonist activity [41, 42], and not commercially available, were chemically synthesized (Fig. 1), and their massspectrometric behavior under electron ionization (EI) was studied. A procedure to detect these compounds in spiked urine specimens using GC/EI-MS employing selected ion monitoring (SIM) was developed and validated according to existing guidelines. Although the metabolism of these SARMs has not been described in the scientific literature yet, an in vitro metabolism study is under way in our laboratories [43].

\section{Experimental}

Chemicals and reagents

17a-Methyltestosterone, methanol, tert-butyl methyl ether (TBME), $\beta$-glucuronidase (from Escherichia coli), dithioerythritol, ammonium iodide ( $\mathrm{NH} 4 \mathrm{I})$, sodium hydrogen carbonate ( $\mathrm{NaHCO} 3)$, sodium carbonate $(\mathrm{Na} 2 \mathrm{CO} 3)$, sodium phosphate dibasic dehydrate $(\mathrm{Na} 2 \mathrm{HPO} 4 \cdot 2 \mathrm{H} 2 \mathrm{O})$, and potassium phosphate monobasic (KH2PO4) were from Sigma-Aldrich (Milan, Italy). N-Methyl$\mathrm{N}$-trimethylsilyltrifluoroacetamide (MSTFA) was obtained from Merck (Darmstadt, Germany). All solution and buffers were prepared using deionized water obtained from a Milli- $Q$ system (Millipore, Billerica, USA). Phosphate buffer ( $0.1 \mathrm{M})$ was prepared by dissolving $4.63 \mathrm{~g}$ of KH2PO4 and 11.75 $\mathrm{g}$ of $\mathrm{Na} 2 \mathrm{HPO} 4 \cdot 2 \mathrm{H} 2 \mathrm{O}$ in $1 \mathrm{~L}$ of water, whereas carbonate buffer was prepared by dissolving $2.12 \mathrm{~g}$ of $\mathrm{Na} 2 \mathrm{CO} 3$ and $6.72 \mathrm{~g}$ of $\mathrm{NaHCO} 3$ in $1 \mathrm{~L}$ of water.

Synthesis and characterization of model compounds

Quinolinone-derived SARMs were prepared as described elsewhere according to established procedures $[44,45]$. Target compounds were characterized by high-resolution/high-accuracy MS using an LTQ Orbitrap (Thermo, Bremen, Germany) employing an electrospray ionization source operating in positive mode, and nuclear magnetic resonance (NMR) spectroscopy with $1 \mathrm{H}$, distortionless enhancement by polarization transfer, and $13 \mathrm{C}$ experiments employing a Bruker Avance 300 instrument (Bruker, Karlsruhe, Germany).

Stock and working solution

Stock standard solution were prepared in methanol at a concentration of $1,000 \mu \mathrm{g} / \mathrm{mL}$ and were stored at $-20{ }^{\circ} \mathrm{C}$ until used. Working solutions were prepared at $10 \mu \mathrm{g} / \mathrm{mL}$ by dilution with methanol. 
Gas chromatography/electron ionization-mass spectrometry GC/MS determinations were performed using a $6890 \mathrm{~N}$ gas chromatograph (Agilent Technologies, Milan, Italy) equipped with a 17-m fused-silica capillary column (J\&W Scientific HP-1), of 0.2-mm inner diameter and 0.11- $\mu \mathrm{m}$ film thickness, for GC separation. Helium was employed as the carrier gas at a constant pressure of 20.16 psi. The gas chromatograph oven temperature was set at $120{ }^{\circ} \mathrm{C}$ for $3 \mathrm{~min}$ and then raised to $315{ }^{\circ} \mathrm{C}$ with a $15{ }^{\circ} \mathrm{C} / \mathrm{min}$ heating rate. The total run time was $16 \mathrm{~min}$. The gas chromatograph injector and transfer line were maintained at $280^{\circ} \mathrm{C}$. Fragmentation patterns of trimethylsilyl derivatives were investigated using a 5975 inert mass-selective detector (Agilent Technologies, Milan, Italy) with El at $70 \mathrm{eV}$. Three diagnostic ions of each analyte were chosen and acquired for qualitative analyses using SIM at dwell times of $50 \mathrm{~ms}$.

\section{Sample preparation}

The sample preparation involved minor modifications from the standard operating procedure described by Donike et al. [46] for the detection of anabolic steroids. Urine samples (3 $\mathrm{mL})$ were fortified with $150 \mathrm{ng}$ of the internal standard (ISTD) 17a-methyltestosterone, and then were buffered to $\mathrm{pH} 7.4$ with $2 \mathrm{~mL}$ of a $0.1 \mathrm{M}$ phosphate buffer. $\beta$-Glucuronidase $(30 \mu \mathrm{L})$ was subsequently added and the mixture was incubated at $55^{\circ} \mathrm{C}$ for $1 \mathrm{~h}$. Once the hydrolysis was complete, the mixtures were cooled to room temperature and $2 \mathrm{~mL}$ of $0.1 \mathrm{M}$ carbonate buffer was added to raise the $\mathrm{pH}$ to 9.6. Liquid-liquid extraction was performed by adding $10 \mathrm{~mL}$ of TBME and shaking the mixture in a multimixer for $10 \mathrm{~min}$. After centrifugation at 2,200 rpm for $3 \mathrm{~min}$, the organic layer was transferred into a vial and dried under nitrogen at $70{ }^{\circ} \mathrm{C}$. The dry residue was derivatized with $50 \mu \mathrm{L}$ of an MSTFA/ NH4I/dithioerythritol $(1,000: 2: 4$, v/w/w) solution for $30 \mathrm{~min}$ at $70{ }^{\circ} \mathrm{C}$. A $1-\mu \mathrm{L}$ aliquot was injected into the GC/MS system with a split ratio of 10:1.

\section{Method validation}

Method validation was performed according to ISO 17025 requirements and WADA and ICH guidelines [47, 48]. Therefore, the qualitative determination of the 2-quinolinone-derived SARMs in human urine was validated for linearity, specificity, limit of detection (LOD), precision, and recovery. Blank urine specimens required for the method validation were obtained from ten different healthy volunteers (four female, six male).

\section{Specificity}

Ten different blank urine samples were prepared as described already. The occurrence of possible interferences from endogenous substances or derivatization byproducts was tested by monitoring 
the selected-ion chromatograms, characteristic for each compound investigated, at the retention time interval expected for their elution.

\section{Linearity}

The linear calibration model was checked by analyzing blank urine samples spiked with standard solutions at concentrations of $5,10,25,50,100,250$, and $500 \mathrm{ng}$ of each analyte per milliliter of urine. 17a-Methyltestosterone at a final concentration of $50 \mathrm{ng} / \mathrm{mL}$ was used as the ISTD. The linear calibration parameters were obtained using the least-squares regression method, whereas the correlation coefficient (R2) was utilized to estimate linearity. Quantitative results from area counts were corrected using the ISTD signal.

\section{Limit of detection}

LODs were estimated as the analyte concentrations whose response provided a signal-to-noise $(\mathrm{S} / \mathrm{N})$ ratio of 3 , as determined from the least abundant qualifier ions. The $\mathrm{S} / \mathrm{N}$ ratios at the lowest concentration were used to extrapolate the theoretical LOD. These calculated LODs were then experimentally confirmed by analyzing urine samples spiked with all analytes at the LOD concentrations.

\section{Recovery}

The recovery of each compound was determined at 10, 100, and $500 \mathrm{ng} / \mathrm{mL}$. Mean extraction recovery values were obtained by comparing two experimental sets of data. In the first set, ten blank urine samples were spiked before the extraction step with target compounds, whereas in the second set, ten blank urine samples were spiked after the extraction step, with standard working solutions, at the same final concentration. For both sets of samples, the TBME layer was spiked with $150 \mathrm{ng}$ of ISTD before evaporation. Recovery (\%) was calculated as the ratio between the response (analyte peak area/ISTD peak area) obtained from the two separate series of samples. Recovery values exceeding $75 \%$ were considered satisfactory.

Intraday precision

Intraday precision, expressed as percent coefficient of variation (CV\%), was assessed by extracting and analyzing, within 1 day, ten replicates of blank urine samples, spiked with the standard solutions at three concentrations (final concentrations of 10,100 , and $500 \mathrm{ng} / \mathrm{mL}$ for each analyte), performed by the same operator. 
Interday precision

On three consecutive days, ten urine samples with low $(10 \mathrm{ng} / \mathrm{mL})$, medium $(100 \mathrm{ng} / \mathrm{mL})$, and high (500 ng/mL) concentrations of target compounds were prepared and analyzed by the same operator. Interday precision, expressed as CV\%, was calculated for each concentration. The interday/intraday precision was considered satisfactory when the CV\% values were below $15 \%$ at high concentrations and below $25 \%$ at low concentration.

\section{Results and discussion}

Synthesis and characterization of model compounds The syntheses provided sufficient amounts of the desired structures as pure analytes necessary for method development and structural characterization; the purities were greater than $95 \%$ in all cases. Accurate mass measurement allowed the determination of the elemental composition of protonated molecules: compound 1 elemental composition $\mathrm{C} 14 \mathrm{H} 11 \mathrm{O} 2 \mathrm{~N} 2 \mathrm{~F} 6, \mathrm{~m} / \mathrm{z}$ (theoretical) $353.0719 \mathrm{~m} / \mathrm{z}$ (experimental) 353.0725, error 1.7 ppm; compound 2 elemental composition C15H16ON2F3, m/z (theoretical) $297.1209, \mathrm{~m} / \mathrm{z}$ (experimental) 297.1215, error 2.0 ppm. Model SARMs were characterized by NMR analyses.

Compound 1: 1H NMR [300 MHz, dimethyl-d6 sulfoxide (d6-DMSO)] $\delta 11.98$ (br s, 1H, NH), 6.92 (s, 1H, 8-H), 6.84, $6.74(2 \mathrm{~s}, 2 \times 1 \mathrm{H}, 5-\mathrm{H}$ and 10-H), $4.28(\mathrm{t}, 2 \mathrm{H}, \mathrm{J}=4.2 \mathrm{~Hz}, 3-\mathrm{H}), 4.20$ (q, 2H, J=9.6 $\mathrm{Hz}, \mathrm{CH} 2 \mathrm{CF}$ ), 3.52 (t, $2 \mathrm{H}, \mathrm{J}=4.2 \mathrm{~Hz}, 2-\mathrm{H}) .13 \mathrm{C}$ NMR (75 MHz, d6-DMSO) $\delta$ 159.8, 148.1, 136.0 (q, $\mathrm{J}=30.4 \mathrm{~Hz}), 134.1,130.7,125.6$ (q, J=281.1 Hz), 122.6 (q, J=273.2 Hz), 118.4 (q, J=4.7 Hz), 107.9, 105.5, 102.8, 64.6, 51.9 (q, J=32.1 Hz), 47.8.

Compound 2: 1H NMR (300 MHz, CD3OD) $\delta 7.30$ (s, $1 \mathrm{H}, 5-\mathrm{H}), 6.46(\mathrm{~s}, 1 \mathrm{H}, 7-\mathrm{H}), 6.37$ (s, 1H, 10$\mathrm{H}), 3.31(\mathrm{~m}, 2 \mathrm{H}, 2-\mathrm{H}), 2.69(\mathrm{~m}, 1 \mathrm{H}, 4-\mathrm{H}), 1.86(\mathrm{~m}, 2 \mathrm{H}, 3-\mathrm{H}), 1.60(\mathrm{~m}, 2 \mathrm{H}, \mathrm{CH} 2 \mathrm{CH} 3), 0.99(\mathrm{t}, 3 \mathrm{H}$, $\mathrm{CH} 2 \mathrm{CH} 3$ ). 13C NMR (75 MHz, CD3OD/d6-DMSO 1:1) $\delta$ 163.0, 149.4, 141.2, 138.9 (q, J=30,6 Hz), 124.9, 123.9 (q, J=275.6 Hz), 123.4, 112.7 (q, J=5.6 Hz), 104.9, 96.9, 38.2, 37.8, 28.8, 25.5, 11.5.

Interpretation of electron ionization mass spectra

A comprehensive assignment of the ultimate structures to El mass fragments is beyond the scope of this study. However, a highly liable interpretation of El mass spectra is made possible by comparison with definitive studies on homologue SARMs [26, 33]. The mass spectrum of the trimethylsilyl derivative of 1 (Fig. 2) shows a molecular ion at $\mathrm{m} / \mathrm{z} 424$. The base peak at $\mathrm{m} / \mathrm{z} 409$ is generated by the loss of a methyl radical $(-15 \mathrm{u})$ from the trimethylsilyl residue. The subsequent elimination of trifluoroethane $(-84 \mathrm{u})$ leads to a fragment ion at $\mathrm{m} / \mathrm{z} 325$. The release of a trifluoromethyl radical $(-69 \mathrm{u})$ from the molecular ion produces the fragment ion at $\mathrm{m} / \mathrm{z} 355$. According to previous studies on 2-quinolinone-derived SARMs [26, 32, 33], the trifluoromethyl 
radical located on the aromatic ring is identified as the leaving group and cleavage of the cyclic structure was suggested. The subsequent loss of trifluoroethane $(-84 \mathrm{u})$ or acetaldehyde $(-44 \mathrm{u})$ possibly yields the fragment ion at $\mathrm{m} / \mathrm{z} 271$ or $\mathrm{m} / \mathrm{z} 311$, respectively. Trimethylsilylation of 2 yielded a structure with a molecular mass of $440 \mathrm{u}$. Under El conditions, the molecular ion decomposes to products ions at $\mathrm{m} / \mathrm{z} 425,395,351,411$, and 337 (Fig. 3). The first three fragments most likely arise from loss of a methyl radical $(-15 \mathrm{u})$ followed by the elimination of ethane $(-30 \mathrm{u})$ or trimethylsilane $(-74 \mathrm{u}$ ), giving the fragments at $\mathrm{m} / \mathrm{z} 395$ and $\mathrm{m} / \mathrm{z} 351$, respectively. The fragment at $\mathrm{m} / \mathrm{z} 411$ reasonably results from the loss of an ethyl radical $(-29 \mathrm{u})$ from the molecular ion, whereas a consecutive elimination of a trimethylsilane molecule $(-74 \mathrm{u})$ could be hypothesized to justify the fragment ion at $\mathrm{m} / \mathrm{z} 337$.

\section{Method validation}

On the basis of the mass-spectrometric data, three diagnostic ions of each analyte were chosen and acquired for qualitative analyses according to WADA guidelines: compound $1 \mathrm{~m} / \mathrm{z} 409,424$, and 355 (Fig. 2); compound 2m/z 440, 425, 411 (Fig. 3); ISTD m/z 301, 446, and 431. A SIMGC/MS chromatogram obtained from a blank urine specimen fortified with $5 \mathrm{ng} / \mathrm{mL}$ of each compound is illustrated in Fig. 4.

\section{Specificity}

Evaluating ten blank urines for endogenous interferences, we observed no quantifiable analyte peaks (i.e., S/N ratio less than 3 ) at the expected retention time. This demonstrated that the method is selective for the compounds tested and is free from positive interference from urine components and column bleeding.

\section{Linearity}

The range of concentration studied was planned according to the approximate response factors obtained from the preliminary experiments with standard solutions. The calibration plots show good linearity for both SARMs under study in the interval $5-500 \mathrm{ng} / \mathrm{mL}$. The coefficient of correlation (R2) was 0.9983 and 0.9991 , respectively, for compounds 1 and 2. 
Limit of detection

LODs for both compounds were estimated from calculation (see "Experimental") at $1 \mathrm{ng} / \mathrm{mL}$ (Table 1). Estimated LODs were experimentally confirmed by analyzing in triplicate a blank urine sample spiked with the target analytes at the LOD concentrations. All S/N ratios observed exceeded the critical value of 3 , as expected. For this class of substances, the WADA requirements do not establish a limit for the minimum required performance, whereas for anabolic agents the fixed minimum required performance is $10 \mathrm{ng} / \mathrm{mL}$ [49]. Therefore, the LOD of $1 \mathrm{ng} / \mathrm{mL}$ measured for these SARMs appears satisfactory in comparison with what is required for anabolic steroids or experimentally determined for other anabolic agents, including other SARMs (0.2 ng/mL) [33].

\section{Recovery}

Recovery values are reported in Table 1. The recoveries of compounds 1 and 2 were 101.2 and 99.5\%, respectively, for the low level, 99.3 and $95.5 \%$ for the medium level, and 96.7 and $96.6 \%$ for the high level. These high recovery values, obtained by applying a well-established extraction procedure for anabolic steroids, clearly indicate that the new target analytes could be directly included in existing drug screening procedures.

Intraday and interday precision

The retention time and the relative abundances of the characteristic ions were respected for all tests. Repeatability of the retention times was excellent, with $C V \%$ values below $0.1 \%$ for the analytes at 10,100 , and $500 \mathrm{ng} / \mathrm{mL}$ and for the ISTD at $50 \mathrm{ng} / \mathrm{mL}$. Repeatability of the relative abundances for the characteristic ions was satisfactory. At the three concentrations tested, for compound $1, \mathrm{CV} \%$ values were below $5 \%$ for all ions monitored, whereas for compound 2 and ISTD, CV\% values were below $2.5 \%$ for all ions monitored. The values obtained show a satisfactory intraday precision represented by CV\% lower than $15 \%$ for the samples spiked at 10 and $100 \mathrm{ng} / \mathrm{mL}$ and $10 \%$ for the samples spiked at $500 \mathrm{ng} / \mathrm{mL}$ (Table 1). The interday precision of the method, expressed as CV\%, was lower than $20 \%$ for the samples spiked at 10 and $100 \mathrm{ng} / \mathrm{mL}$ and $15 \%$ for the samples spiked at $500 \mathrm{ng} / \mathrm{mL}$ (Table 1). According to standard criteria taken from the literature that designate satisfactory intra-assay precision for qualitative screening methods when $\mathrm{CV} \%$ values are below $15 \%$ at high concentrations and below $25 \%$ at lower concentrations [50], the method demonstrated satisfactory reproducibility. 


\section{Conclusions}

In sport doping, the misuse of new drugs often anticipates the completion of their clinical trials and their industrial production and marketing. This is the case for several SARMs, whose administration induces anabolic/androgenic effects without the occurrence of most side effects typical of anabolic androgenic steroids. For this reason, it is necessary to continuously update the analytical procedures devoted to doping control, to include the new drugs as soon as they become available. In this study two model compounds representing quinolinone-based SARMs were synthesized and included in a validated GC/MS method to provide chromatographic and massspectral data useful to doping control laboratories. The analysis of these drugs in urine samples for antidoping purposes has never been published before. Future studies, including in vitro metabolism experiments, will provide further awareness about potential metabolic products to improve screening and confirmation methods in sport drug testing.

\section{References}

1. Mooradian AD, Morley JE, Korenman SG (1987) Endocr Rev 8:1-8

2. Bagatell CJ, Bremner WJ (1996) N Engl J Med 334:707-714

3. Bhasin S, Bremner WJ (1997) J Clin Endocrinol Metab 82:3-8

4. Saad F, Kamischke A, Yassin A, Zitzmann M, Schubert M, Jockenhel F, Behre HM, Gooren L, Nieschlag E (2007) Asian J Androl 9:291-297

5. Nieschlag E (2010) Handb Exp Pharmacol 198:197-223

6. Benéton MN, Yates AJ, Rogers S, McCloskey EV, Kanis JA (1991) Clin Sci 81:543-549

7. Hamdy RC, Moore SW, Whalen KE, Landy C (1998) Am J Ther 5:89-95

8. Kuhn CM (2002) Recent Prog Horm Res 57:411-434

9. Parkinson AB, Evans NA (2006) Med Sci Sports Exerc 38:644-651

10. Casavant MJ, Blake K, Griffith J, Yates A, Copley LM (2007) Pediatr Clin N Am 54:677-690

11. Negro-Vilar A (1999) J Clin Endocrinol Metab 84:3459-3462

12. Chen F, Rodan GA, Schmidt A (2002) Natl J Androl 8:162-168

13. Chen J, Hwang DJ, Bohl CE, Miller DD, Dalton JT (2005) J Pharmacol Exp Ther 312:546-553

14. Chen J, Kim J, Dalton JT (2005) Mol Interv 5:173-188

15. Cadilla R, Turnbull P (2006) Curr Top Med Chem 6:245-270

16. Gao W, Dalton JT (2007) Drug Discov Today 12:241-248

17. Kilbourne EJ, Moore WJ, Freedman LP, Nagpal S (2007) Curr Opin Investig Drugs 8:821-829

18. Gao W, Kim J, Dalton JT (2006) Pharm Res 23:1641-1658

19. Gao W, Dalton JT (2007) Mol Interv 7:10-13

20. Narayanan R, Mohler ML, Bohl CE, Miller DD, Dalton JT (2008) Nucl Recept Signal 6:e10 
21. Zhang X, Lanter JC, Sui Z (2009) Expert Opin Ther Pat 19:1239-1258

22. Mohler ML, Bohl CE, Jones A, Coss CC, Narayanan R, He Y, HwangDJ, Dalton JT,Miller DD(2009) J Med Chem52:3597-3617

23. Wu D, Wu Z, Yang J, Nair VA, Miller DD, Dalton JT (2006) Drug Metab Dispos 34:483-494

24. Gao W, Wu Z, Bohl CE, Yang J, Miller DD, Dalton JT (2006) Drug Metab Dispos 34:243-253

25. Kuuranne T, Leinonen A, Schänzer W, Kamber M, Kostiainen R, Thevis M (2008) Drug Metab Dispos 36:571-581

26. Thevis M, Schänzer W (2008) J Mass Spectrom 43:865-876

27. Thevis $M$, Kohler M, Maurer J, Schlörer N, Kamber M, Kühn A, Schänzer W (2008) J Mass Spectrom 43:639-650

28. Thevis M, Thomas A, Kohler M, Beuck S, Schänzer W (2009) J Mass Spectrom 44:442-460

29. Thevis M, Geyer H, Kamber M, Schänzer W (2009) Drug Test Anal 1:387-392

30. World Anti-Doping Agency (2010) The 2010 prohibited list. http://www.wadaama.org/Documents/World_Anti-Doping_Program/WADP-Prohibited-

list/WADA_Prohibited_List_2010_EN.pdf. Accessed 14 Jul 2009

31. Thevis M, Kamber M, Schänzer W (2006) Rapid Commun Mass Spectrom 20:870-876

32. Thevis M, Kohler M, Maurer J, Schlörer N, Kamber M, Schänzer W (2007) Rapid Commun Mass Spectrom 21:3477-3486

33. Thevis M, Kohler M, Schlörer N, Fußhöller G, Schänzer W (2008) Eur J Mass Spectrom 14:153-161

34. Thevis M, Kohler M, Thomas A, Schlörer N, Schänzer W (2008) Rapid Commun Mass Spectrom 22:2471-2478

35. Thevis M, Kohler M, Thomas A, Maurer J, Schlörer N, Kamber M, Schänzer W (2008) Anal Bioanal Chem 391:251-261

36. Thevis M, Beuck S, Thomas A, Kohler B, Kohler M, Rodchenkov G, Schänzer W (2009) Rapid Commun Mass Spectrom 23:1139-1146

37. Luosujärvi L, Haapala M, Thevis M, Saarela V, Franssila S, Ketola RA, Kostianen R, Kotiaho T (2010) J Am Soc Mass Spectrom 21:310-316

38. Thevis M, Lohmann W, Schrader Y, Kohler M, Bornatsch W, Karst U, Schänzer W (2008) Eur J Mass Spectrom 14:163-170

39. Thevis M, Thomas A, Fußhöller G, Beuck S, Geyer H, Kamber M, Schänzer W (2010) Rapid Commun Mass Spectrom 24:2245-2254

40. Thevis M, Kuuranne T, Geyer H, Schänzer W (2010) Drug Test Anal 2:149-161

41. Hamann LG, Mani NS, Davis RL, Wang XN, Marschke KB, Jones TK (1999) J Med Chem 44:103-114

42. Mohler ML, Nair VA, Hwang DJ, Rakov IM, Patil R, Miller DD (2005) Expert Opin Ther Pat 15:1565-1585 
43. Costa R (2010) Agenti dopanti di ultima generazione: strategie analitiche per la determinazione di modulatori selettivi del recettore androgenico (SARM) in fluidi biologici. MS thesis, Università degli Studi di Torino, Turin. Abstract available at https://wall.rettorato.

unito.it/sia/studenti/intesi/Ricerca_tesi_libera/ricerca_tesi_dettaglio.

asp?id_upload=26843\&cdl_tesi=227\&cdl=8\&matricola=335635. Accessed 23 Nov 2010

44. Higuchi RI, Edwards JP, Caferro TR, Ringgenberg JD, Kong JW, Hamann LG, Arienti KL, Marschke KB, Davis RL, Farmer LJ, Jones TK (1999) Bioorg Med Chem Lett 9:1335-1340

45. Higuchi RI, Arienti LA, Lòpez FJ, Mani NS, Mais DE, Caferro TR, Long YO, Jones TK, Edwards JP, Zhi L, Schrader WT, Negro-Vilar A, Marschke KB (2007) J Med Chem 50:2486-2496

46. Donike M, Geyer H, Gotzmann A, Kraft M, Mandel F, Nolteernsting E, Opfermann G, Sigmund G, Schänzer W, Zimmermann J (1988) In: Bellotti P, Benzi G, Ljungquist A (eds) Official proceedings of the International Athletic Foundation world symposium on doping in sport. AAF, Florence

47. World Anti-Doping Agency (2010) International standard for laboratories, version 6.0. http://www.wada-ama.org/Documents/World_Anti-Doping_Program/WADP-IS-Laboratories/ WADA_Int.Standard_Laboratories_2009_EN.pdf. Accessed 11 Jun 2010

48. International Conference on Harmonisation (2004) Validation of analytical procedures: methodology. http://www.ich.org/LOB/media/MEDIA417.pdf. Accessed 20 Jul 2010

49. World Anti-Doping Agency (2010) Minimum required performance limits for detection of prohibited substances - WADA technical document - TD2010MRPL. http://www.wadaama.org/Documents/World_Anti-Doping_Program/WADP-IS-

Laboratories/WADA_TD2010MRPLv1.0_Minimum_Required_Performance_ Levels_Sept_01_2010_EN.pdf. Accessed 18 Sep 2010

50. Jiménez C, Ventura R, Segura J (2002) J Chromatogr B Anal Technol Biomed Life Sci $767: 341-351$ 


\begin{tabular}{cccccc}
\hline Compound & $\begin{array}{c}\text { LOD } \\
(\mathrm{ng} / \mathrm{mL})\end{array}$ & $\begin{array}{c}\text { Tested } \\
(\mathrm{ng} / \mathrm{mL})\end{array}$ & $\begin{array}{c}\text { Recovery } \\
(\%)\end{array}$ & $\begin{array}{c}\text { Intraday precision } \\
\text { CV }(\%)\end{array}$ & $\begin{array}{c}\text { Interday precision } \\
\text { CV }(\%)\end{array}$ \\
\hline $\mathbf{1}$ & 1 & 10 & 101.2 & 14.8 & 10.6 \\
& & 100 & 99.3 & 10.1 & 14.2 \\
& & 500 & 96.7 & 9.4 & 10.1 \\
\hline $\mathbf{2}$ & 1 & 10 & 99.5 & 12.2 & 16.2 \\
& & 100 & 95.5 & 8.7 & 9.1 \\
& & 500 & 96.6 & 8.1 & 9.5 \\
\hline
\end{tabular}

${ }^{\mathrm{a}}$ Concentration levels for recovery and precision determination

Table 1. Summary of assay validation results 

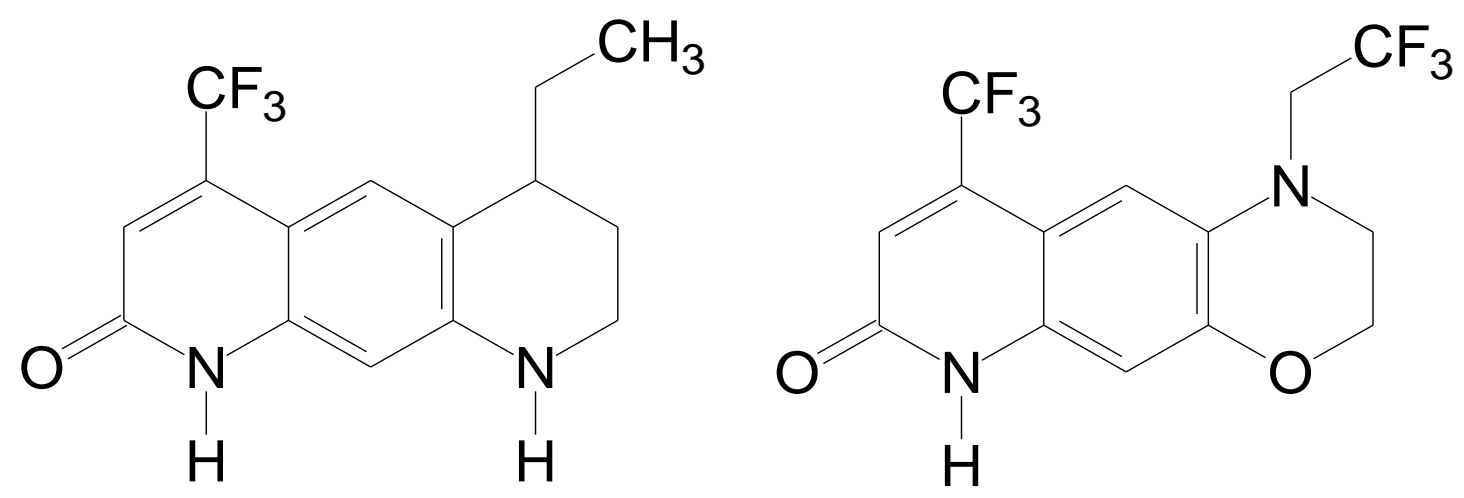

Fig. 1 Chemical structures of investigated compounds: 1 US 6,462,038 (Mw=352), 2 LG 121071 (Mw=296) 


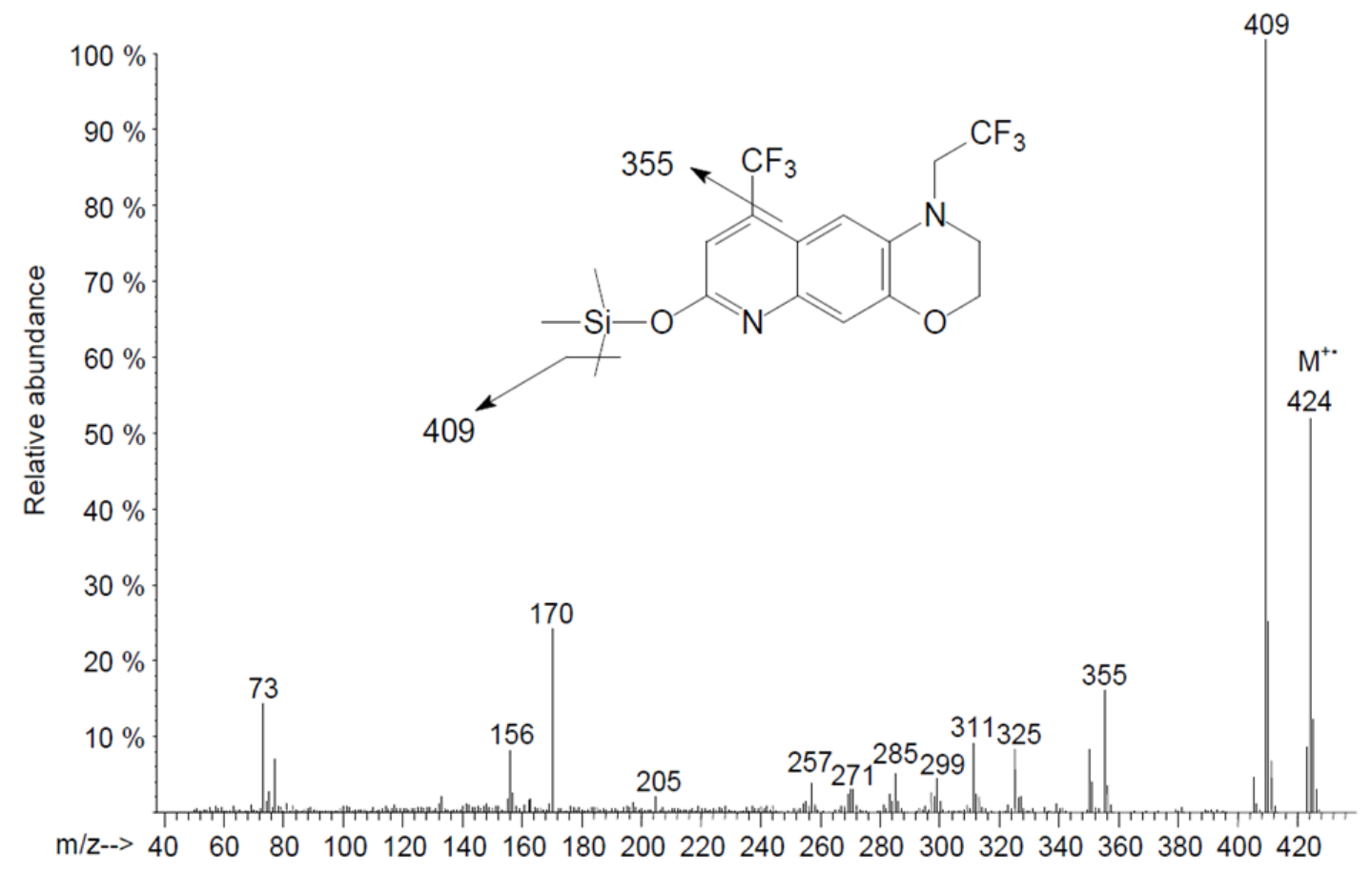

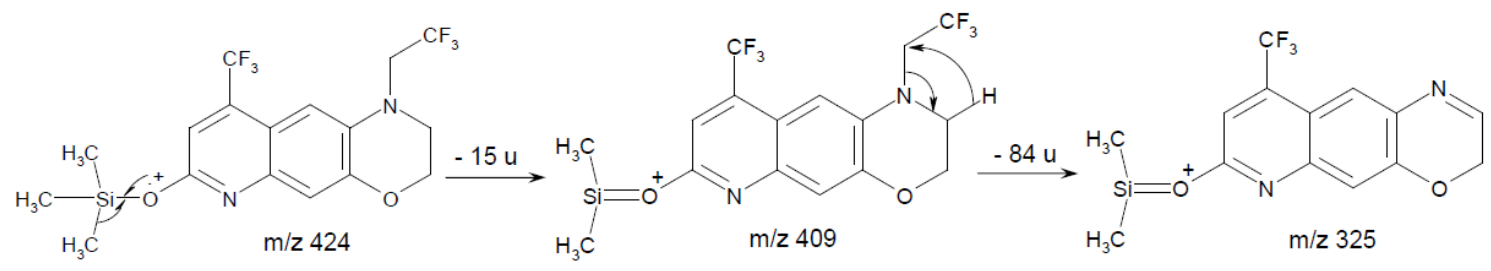<smiles>C#Cc1cc2c(cc1N=C=O)OCC=N2</smiles><smiles></smiles>

Fig. 2 Mass spectrum and proposed fragmentation routes of the TMS-derivative of compound $\mathbf{1}$ after EI. 


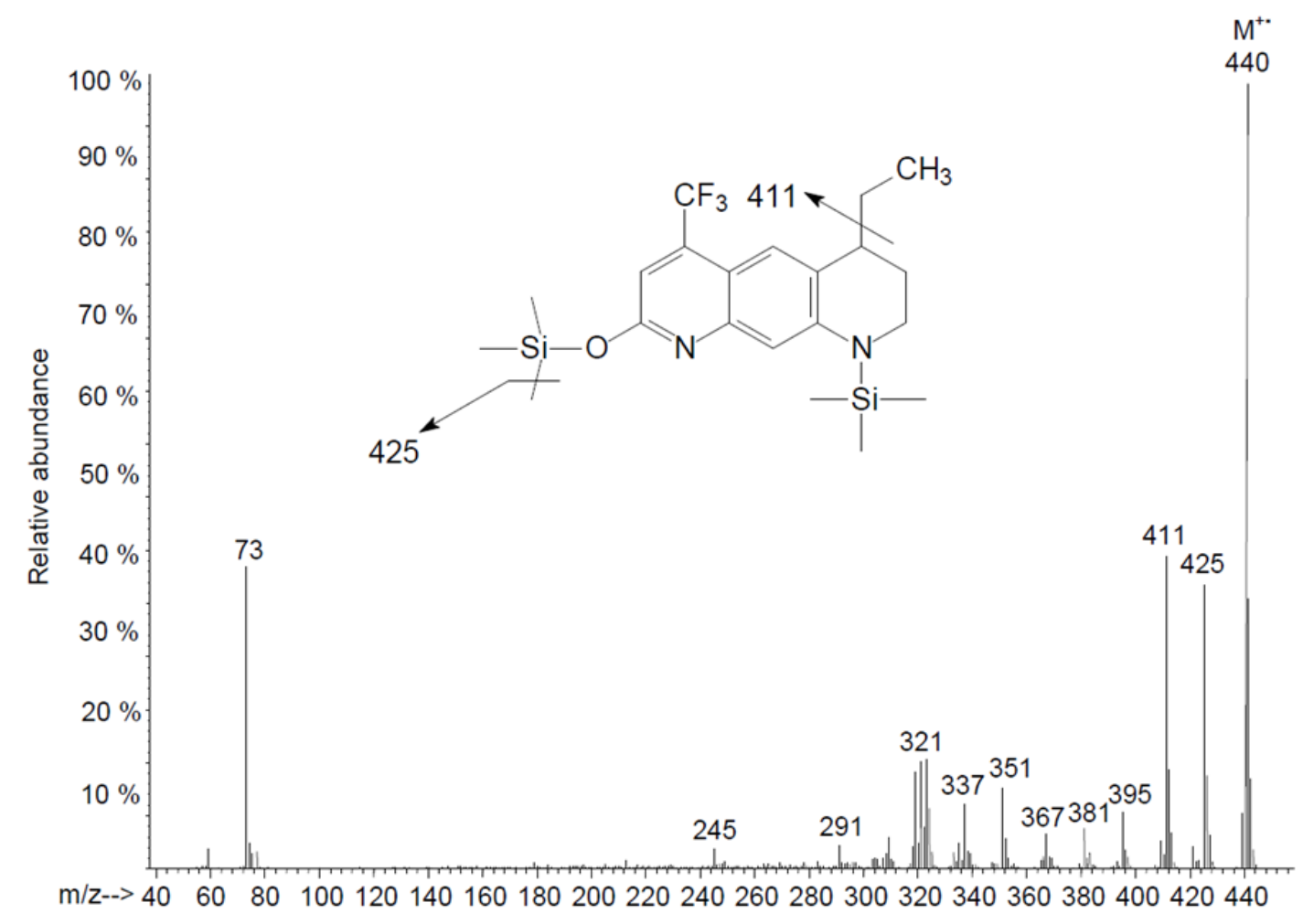

m/2 440

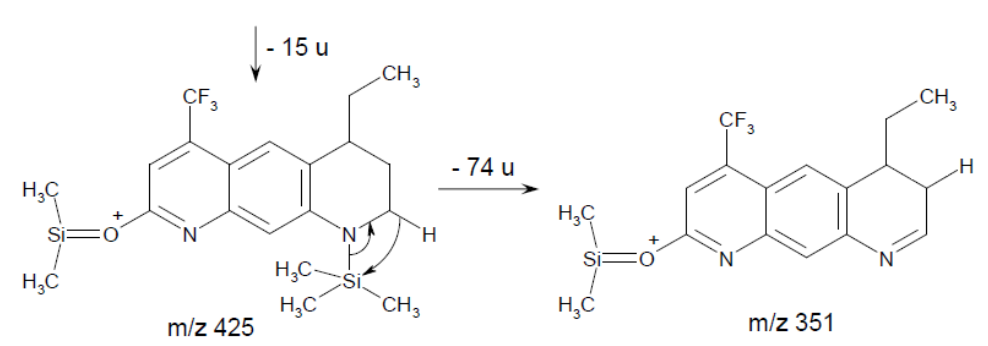

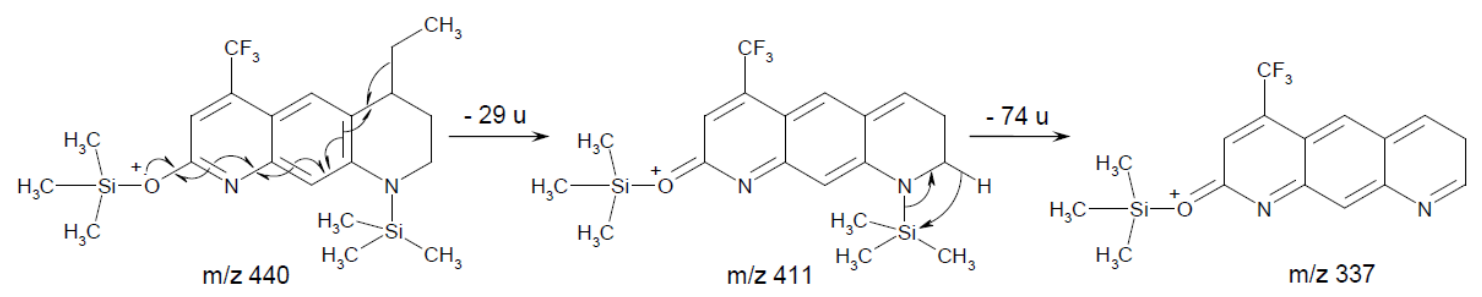

Fig. 3 Mass spectrum and proposed fragmentation routes of the TMS-derivative of compound 2 after EI. 


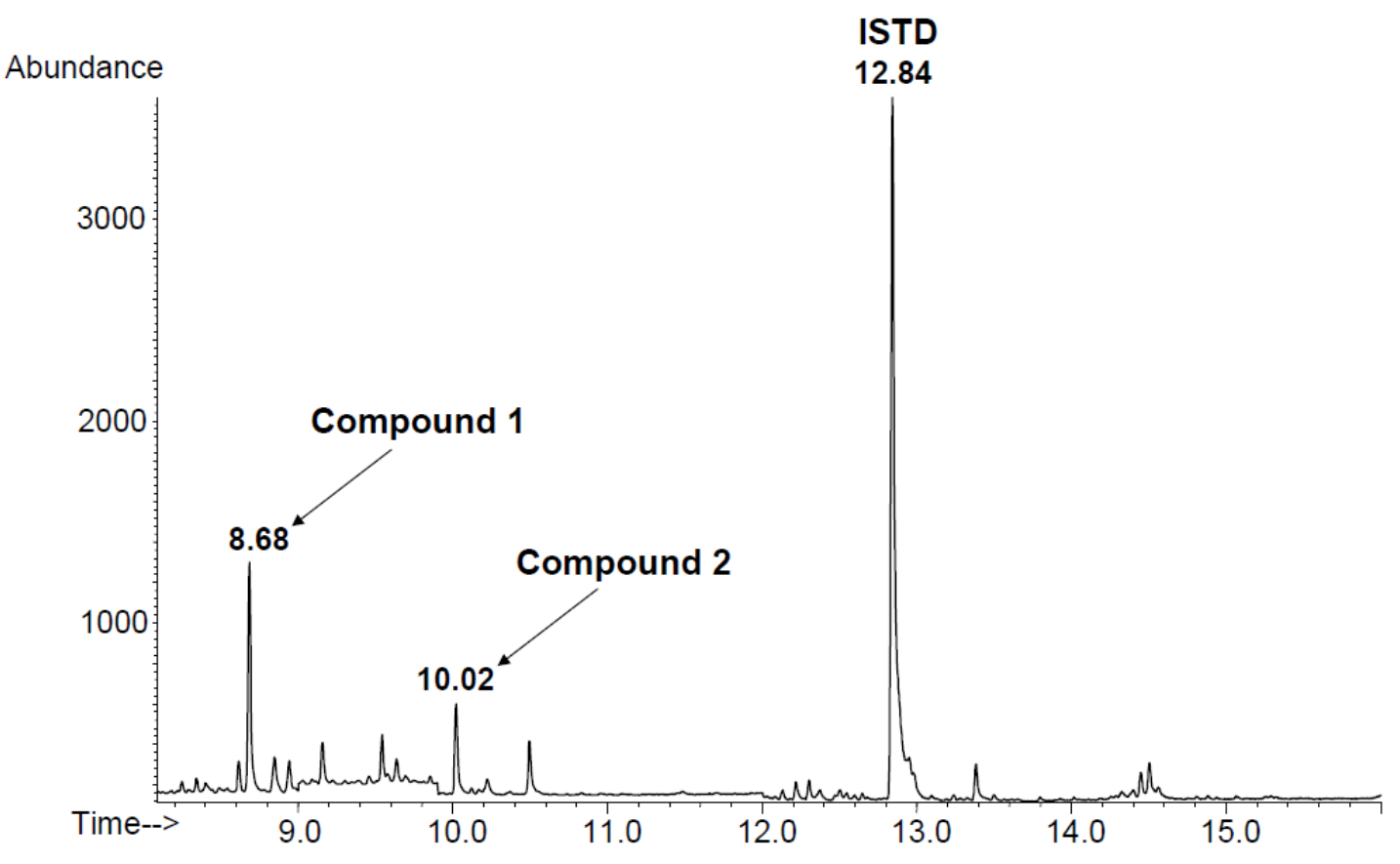

Fig. 4 GC/MS-SIM chromatogram of a blank urine fortified with the target compounds at the concentration of $5 \mathrm{ng} / \mathrm{mL}$ 